\title{
MODEL OF THE REPRESENTATIVE GEOECOSYSTEM AT REGIONAL LEVEL
}

\author{
ZITA IZAKOVIČOVÁ, MILENA MOYZEOVÁ
}

Institute of Landscape Ecology, Slovak Academy of Sciences, Štefánikova 3, P.O.Box 254, 81499 Bratislava, Slovak Republic; e-mail: zita.izakovicova@savba.sk, milena.moyzeova@savba.sk

\begin{abstract}
Izakovičová Z., Moyzeová M.: Model of the representative geoecosystem at regional level. Ekológia (Bratislava), Vol. 38, No. 4, p. 392-400, 2019.

The paper is aimed at the presentation of the new conception of nature protection. The new conception is based on the creation and protection of the representative geoecosystems. The strategic aim of defining the representative geo-ecosystem is: to determine a representative geo-ecosystem for each territorial unit on the given hierarchical level - the regional principle, to determine a representative occurrence for each type of the geo-ecosystem - the typological principle. The list of types of representative geo-ecosystems should serve as an ecologically based systematic framework for new protected areas (according to the analysis of unsufficiently protected representative geo-ecosystems) designations, as well as for methodical proposals of biocentres of the territorial system of ecological stability. The new approach to nature conservation is based not only on the protection of life forms but also on the protection of living conditions.

The paper presents an example of the creation of representative geoecosystems on the regional level -Trnava region.
\end{abstract}

Key words: representative geoecosystem, region Trnava, territorial system of ecological stability, integrated approach.

\section{Introduction}

Healthy ecosystems are the basis of life and are essential to human well-being and societal prosperity. They provide direct and indirect benefits, including food, clean air and fresh water, shelter and medicine, and they mitigate natural disasters, pests and diseases and contribute to climate regulation. Despite the irreplaceable significance of ecosystems for landscape, they are continually threatened and degraded. According to MEA, $60 \%$ of the world's ecosystems are degraded or used unsustainably; $75 \%$ of fish stocks are over-exploited or significantly depleted and $75 \%$ of the genetic diversity of agricultural crops has been lost worldwide since 1990. Deterioration and loss in ecosystems jeopardise provision of these services. We lose species, habitats and the wealth and employment derived from nature, and we endanger our own well-being (EC, 2011).

Pressures on the use of ecosystems and their services have increased notably in recent years. This is accompanied by increased exploitation, especially emanating from demographic 
change, economic development, a consumer lifestyle, and changing societal behaviour. Increased demand for ecosystem products, including food, raw materials and derived energy, and subsequent land use changes and supply of regulating and supporting services will assume the same or even greater importance in the future. Ecosystem conservation, protection of its functions and efficient use of ES are indispensable for sustainable development and for the preservation of human society. Several initiatives have been taken to address the protection of ecosystems and their services, whether on the professional or political scene (Burkhard et al., 2014; De Groot et al., 2010; Constanza, 2016; Haines-Young, Potschin, 2012; etc.).

The aim of the modern concept of nature and landscape protection of the landscape also in Slovakia is to provide a framework for a prosperous and sustainable society through the protection, rehabilitation, development and sustainable use of ecosystems and their services. In addition to the traditional objectives of protection and conservation of natural heritage for aesthetic, cultural and scientific reasons, new trends in nature conservation also focus on utilitarian values of nature (such as ecological stabilization, self-regulation, conservation of production capacity, gene pool utilization, protective, hygiene and recreational effects). Thus, it is not only about the protection of individual ecosystems, but also about ensuring the efficient use of their ecosystem services (Izakovičová et al., 2017).

The aim of this approach is to maintain suitable living conditions for man as a biological, social and economic species (anthropocentrism), but also suitable conditions for life of other living systems - ecosystems (biocentrism). The current level of knowledge unequivocally confirms that the conditions of human life are sustainable only if the living conditions for all other species are maintained, which requires preserving the natural functions and relationships of all - including the abiotic - elements of the landscape (geobiocentrism). That is why all science concepts supporting such ecological policy focus on developing principles for preserving natural functions and relationships in geoecosystems.

Thus, the modern concept of nature protection is based on the model of protection of representative geoecosystems (REPGES). REPGES represent landscape units characterized by a certain diversity of conditions - different bedrock, hydrological, pedological, climatic, morphometric conditions, which also cause the occurrence of various forms of ecosystems and biota i.e. life forms. These land units represent a potential for the development of society.

The aim of the paper is to introduce the concept of protection of representative geoecosystems, which represent the basic spatial units for the provision of ecosystem services. We present the methodical procedure at the regional level on example of the Trnava district.

\section{Theory and methodology}

Specific objects and carriers of geoecodiversity are geoecosystems. For most geographers and geosystemologists, the term geosystem is a complex expression of the reality of the landscape. However, for many other natural sciences as well as for the non-professional public, the "geo-" prefix evokes association only with the abiotic part of the landscape, and often only with the bedrock. Therefore, for the avoidance of these doubts, we also accept the possibility of using the "geoeco-" prefix in various terms that emphasize both aspects of the indivisible reality of the landscape, both abiotic conditions and natural systems (Miklós et al., 2006).

The starting point of the strategy of preserving the diversity of conditions and life forms (geoecodiversity) in the above mentioned sense is identifying and defining those geoecosystems that we want to preserve (Odum, 1975; Bunce et al., 1996; Jongman et al., 2006). Thus, the strategic objective of defining representative geoecosystems is 
(Miklós et al., 2006):

- identify a representative geoecosystem for each territorial unit at a given hierarchical level - regional principle,

- determine a representative occurrence for each type of geoecosystem - a typological principle.

In other words:

- each territorial unit must have identified a representative geoecosystem, as well as,

- each type of geoecosystem is representative somewhere (there is a territorial unit where the type has a representative occurrence).

The strategic outcome of this procedure is that representative geoecosystems in each region should be declared as skeleton elements of the territorial system of ecological stability (TSES), i.e. according to our legislation for biocentres or biocorridors and interaction elements. Despite the fact that the nature protection in Slovakia is on a high level on a worldwide scale, in terms of the number, size and quality of protected areas, after elaborating the system scheme of representative geoecosystems and comparing it with protected areas, we can state that many representative geoecosystems are not protected and are in danger of being wiped out. Overall, the conservation of attractive types of REPGES, such as the most interesting rare habitats, exotics, aesthetically impressive communities (e.g. rock communities, karst habitats, alpine habitats) still prevails.

For Slovakia, a system of representative potential geoecosystems (REPGES) was developed at a supra-regional level (Miklós et al., 2006). The aim was to develop a system scheme for the strategy of protecting the diversity of conditions and life forms at the state level, in other words to elaborate a list containing all strategically important geoecosystems of the SR. Subsequently, a methodological procedure for specification of REPGES at regional level was elaborated on the example of Trnava district.

The individual types of REPGES SR were determined on the basis of (Miklós et al., 2006):

- Zonal (bioclimatic) conditions - in the landscape they are mainly expressed by vegetation zones. We characterize them according to bioclimatic conditions, which are comprehensively expressed in 9 zones of potential vegetation.

- Azonal conditions - primarily by quaternary-geological base and relief, secondary by soils and groundwater level. We divided them into 37 types.

In a real landscape, these conditions manifest themselves comprehensively, they cannot be separated. Zonal conditions in the region cannot be changed at all, while azonal - soil, water and relief - can be partially changed or influenced by the use of energy.

The methodology of creation of REPGES at regional level was also based on this methodology. REPGES at regional level have been designated on the basis of synthesis:

a) abiocomplexes - the basis for the processing of abiocomplexes was a digital spatial database of abiocomplexes processed at Slovak Geological Institute Dionýz Štúr within the project Geological maps for the needs of the landscapeecological basis of integrated landscape management (KEZIMK) with a detail corresponding to the scale of 1:50 000 . The database contains spatially delimited (based on 1:10 000) topical synthetic units - (abiocomplexes). The units are described by the following set of parameters relevant to REPGES processing:

- relief: morphographic-morphometric-positional type of relief, average slope,

- geological basis - substrate: lithogenetic characteristics of the substrate, hydrogeological characteristics of the substrate (+ relevant state variables), engineering geological zone (+ relevant state variables), genetic types of quaternary sediments,

- $\quad$ soil: soil subtype, soil type, skeleton, depth, etc.

- climate type,

- groundwater regime for $\mathrm{ABK}$.

Processed parameters were supplemented and revised (simplified, supplemented, reclassified), for the purposes of REPGES creation.

b) map of potential vegetation - represents the vegetation that would have developed in the territory if man had not affected the landscape. It is important to know which natural vegetation units were present in the area and how they were spatially distributed. The characterization of potential vegetation was done on the basis of internal data of the Institute of Geobotany of SAS according to the concept of Michalko et al. (1986).

Study area

Trnava district was chosen as a study area. The administrative boundary of the Trnava district was the basis of the delimitation of the study area. The district is located in the western part of Slovakia. It is part of the Trnava region. 
It is administratively made up of 45 rural municipalities and 1 city of Trnava, which also serves as a regional town. With an area of $741 \mathrm{~km}^{2}$, it belongs to medium-sized districts of Slovakia. Trnava is a typical industrial-agricultural region. According to the last population census, 126382 inhabitants live in the territory.

From the geomorphological point of view, the area consists of two basic geomorphological units - the Danubian Lowland (part of the Trnava Upland and the Danubian Flat) and the Little Carpathians. The core of the territory, i.e. the central and southern part is the Danubian Lowland. The Little Carpathians form the northwestern border of the territory. Geomorphological conditions also determine the characteristics of other landscape-forming components and the occurrence of natural resources and potentials of the territory, which determine the functional use of the territory. The natural resources in the area are dominated by quality soils (chernozem and floodplain soils), which with favorable climate conditions, create a high potential for agricultural development. Agricultural soil of the study area belongs to the best quality and most fertile soils.

There is a high forestry potential in the northern part of the study area. Some of the forests are used for forest management, part of them are protective forests. The forest ecosystems of the study area are characterized by high gene pool and nature conservation value. Most of the forest units of the study area form part of the Little Carpathians Protected Landscape Area (PLA). In the study area there are also numerous protected areas (16 sites) and 4 sites of the Natura 2000 network.

From the environmental aspect, it represents a region with specific environmental problems resulting from the development of industry and agriculture (strong degree of contamination of individual components of the environment, degradation processes of ALF due to incorrect land management, inappropriate crop structure, etc.). It is highly anthropized landscape with a very low degree of ecological stability.

\section{Results}

In total, 95 basic types of REPGES were designated in the Trnava district, resulting from the synthesis of abiocomplexes and types of potential vegetation. Altogether 26 types of abiocomplexes were allocated in four basic categories (plains, uplands, highlands, mountainous areas) and 11 types of potential vegetation determined according to bioclimatic conditions and 4 types determined according to azonal conditions. Individual types of REPGES have different areal representation. The largest share is occupied by the following REPGES (Izakovičová et al., 2011):

- $\quad$ undulating loess plains with oak forests $-16.75 \%$,

- $\quad$ medium rugged loess upland with oak-hornbeam Carpathian forests $-9.87 \%$,

- undulating loess plains with thermophilic Pontic-Pannonian oak forests $-7.38 \%$,

- flat plateaus of loess uphills with oak-hornbeam Carpathian forests $-7.14 \%$,

- medium rugged loess uphills with oak-hornbeam Pannonian forests $-5.47 \%$,

- $\quad$ undulating plains of sand dunes with oak forests $-5.20 \%$.

For 14 REPGES, the area ranges from 1 to $5 \%$. Areas of other REPGES (up to 70 types) do not reach even $1 \%$ of the total area of the district.

During the historical development, the man significantly influenced the structure of the REPGES of the study area, which was manifested mainly by the significant occupation of forest ecosystems (deforestation) and their transformation into agricultural, especially arable land, first into small-block and then large-block arable land. Significant intervention into the structure of REPGES had the intensification of agriculture, which occurred at the time of collectivization and socialization. This meant deforestation and plowing of land. The gradual increase in heavy machinery has led to the elimination of vegetation residues, creating a deforested, ecologically unstable, monotonous, intensively agriculturally exploited landscape. Significant disturbance and significant transformation of REPGES is also evidenced by the 
naturalness coefficient, which reaches zero value in most of the area of the Trnava loess table, which means that all the natural ecosystems were destroyed and converted to semi-natural or artificial ecosystems. The assessment of the conservation/anthropogenic change of individual REPGES types was carried out on the basis of the naturalness coefficient (Miklós et al., 2006), which expresses the current percentage of natural vegetation within each REPGES type. Up to 17 REPGES types have no natural vegetation and up to $27 \%$ of REPGES have no natural vegetation percentage greater than 1\%. 30\% of REPGES types have abundance of natural vegetation over $50 \%$. The structure of abundance of REPGES types on the basis of naturaless coefficient is expressed in Fig. 1.

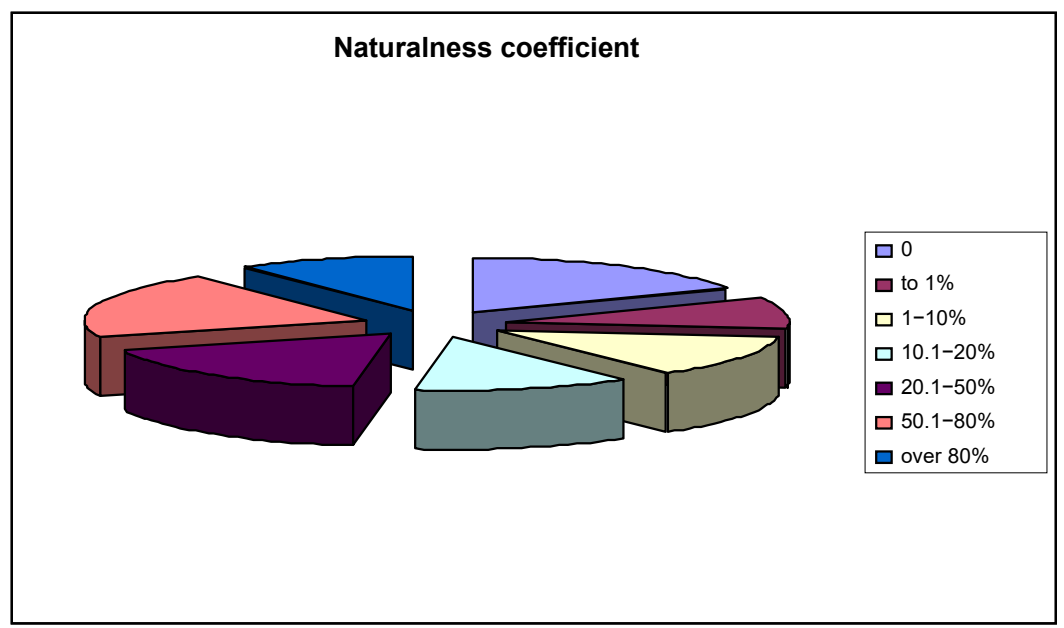

Fig. 1. Naturalness coefficient.

Even now, individual types of REPGES are threatened by the development of human activities. The assessment of the threat of individual REPGES due to stress factors was carried out on the basis of the threat coefficient, which reflects the occurrence of the stressor in the REPGES area and the intensity of its negative effect. 46\% of REPGES types are medium endangered, $38.5 \%$ are severely endangered and $15.5 \%$ are critically endangered, based on this coefficient. REPGES located in the central part of the district on loess tables and loess uplands are critically endangered; REPGES of the highlands and rocks located in the northern part of the district are the least endangered. Most of them are part of the Little Carpathians PLA.

In order to preserve individual types of REPGES, it is necessary to know their degree of protection. Protection of REPGES was evaluated on the basis of the protection coefficient (Miklós et al., 2006), which expresses the proportion of the area of REPGES that falls under the $2^{\text {nd }}$ to $5^{\text {th }}$ degree of protection. The 17 types of REPGES of the study area (17.7\%) show a zero degree of protection. It is the most extensive REPGES of loess tables and loess uplands. The highest level of protection has REPGES No. 84: strongly rugged highland on variegated 
rocks with acidophilous oak forests, of which up to $87.2 \%$ of the area is protected and REPGES No. 88: and No. 89:, where the share of protection is almost 65\%. However, their areas are relatively small. Area of REPGES No. 84: strongly rugged highland on variegated rocks with acidophilous oak forests reaches 12.89 ha, which in percentage represents only $0.02 \%$ of the total area of the district and the area of REPGES no. 88: medium rugged karst lower upland with calciphile beech forests and 89 medium rugged karst lower upland with beech and fir-beech flowery forests together with about 1000 ha, which represents only $1.35 \%$ of the total area of the district. The highest number of REPGES shows a degree of protection in the range of $40-60 \%$, which includes up to 54 types of REPGES (56.25\%). The categorization of REPGES according to the protection coefficient is shown in Fig. 2.

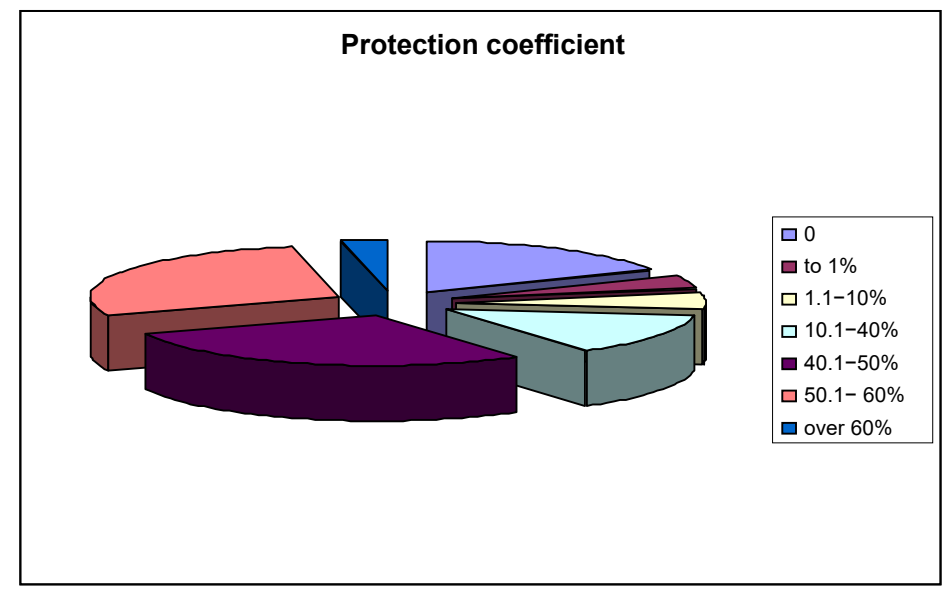

Fig. 2. Protection coefficient.

\section{Discussion}

The identification and characterization of the types of representative geoecosystems should serve as a strategic scheme for a systemically built plan for the preservation of representative conditions and forms of life in a given territory. From a practical point of view, it should serve as an ecologically founded systemic basis for designing new protected areas (by analyzing which representative geoecosystems are at risk and what types of representative geoecosystems are inadequately protected), strengthening the management of nature conservation, as well as the systematic designing biocentres and biocorridors of supra-regional and regional level within the creation of the territorial system of ecological stability (TSES) (Miklós et al., 2018). The basis of biocentres should be made by the individual REPGES and the TSES should be designed in such a way as to ensure maximum representativeness and protection of individual ecosystems. According to the modern concept of nature protection, the basis 
of nature protection is not only the protection of individual life forms but also the protection of their living conditions (Miklós et al., 2006). The concept of ecological networks in the Slovak Republic, known as the territorial system of ecological stability, was also developed on this basis. This, unlike the global concept of ecological networks (Jongman, 1996; Jongman, Kristiansen, 2001; Forman, 1990; Nowicki et al., 1996; Buček, Lacina, 2000; Reháčková, Pauditšová, 2003; Fábos, Ryan, 2004; Izakovičová, Świąder, 2017) does not focus only on protection of life forms, but also on the protection of their conditions. Concept of TSES changes the "classic" idea of the nature conservation based on the division of the landscape to protected and non-protected areas towards a system which maintains the ecological stability of the whole territory by an ecologically suitable spatial structure of the landscape even in the case that it is exploited in different - even in intensive - way. Thus the concept of the TSES is an important tool to secure spatial stability of landscape (Izakovičová et al., 2000).

The TSES is a concise method based on landscape ecological research which modified the ideas of ecological networks towards integrated managment of optimal organisation and utilisation of the landscape as a whole.

The procedure of the TSES contains the basic actions as follows (Izakovičová et al., 2000).

- Delineation of main elements of the TSES: biocentres, biocorridors and interactive elements. Those elements compose the frame of an ecological network. As biocentres should be delineated those biotopes which serves as the basis for food, shelter and site for reproduction, as the biocorridors and interactive elements should be projected chains of biotopes which brake the isolation and ensure the migration and interaction as well as the spatial ecological stability of the landscape.

- Definition and proposal of so called eco-stabilising measures, which should fulfil different practical ecological function as soil and water protection, microclimatic, hygienic, aesthetic and other functions. Among those the agro-technical, agro-ameliorative and forest management measures might be underlined.

At the same time, REPGES are the landscape's basic operational units for assessing ecosystem services. The ES concept focuses on comprehensive research into ecosystems, their functions and the assessment of the benefits that individual ecosystems can provide to society. It is built on an interdisciplinary basis. It seeks to ensure the protection and efficient use of ecosystems and their services so that all ES are used in a harmonious way and that one ES does not develop at the expense of others. Several methods have been developed to assess the ES, whether monetary or non-monetary, participatory, biophysical, etc. The fundamental idea of the ES concept is therefore the usefulness and benefits of nature for society and human well-being. Ecosystem services can very easily be defined as the contribution of ecosystems (living systems) to human well-being. These services are final, as they are the outputs of ecosystems (whether natural, semi-natural or largely altered) that directly affect people's well-being. Their basic attribute is that they retain a link to the associated ecosystem functions, processes and ecosystem structure itself that co-creates them (Haines-Young, Potschin, 2012). Different spatial units are used to assess ecosystem services. The most commonly used and simplest spatial units are land use elements. However, these do not take into account the complex conditions of the landscape system and therefore REPGES may represent new spatial units for the assessment of ecosystem services. 


\section{Conclusion}

The characteristics of the types of representative geoecosystems should serve as an ecologically founded systemic basis for the designing new protected areas as well as a primary basis for the creating functional territorial systems of ecological stability. As already mentioned, representative geoecosystems in each region should be declared as elements of the skeleton of the territorial system of ecological stability; i.e. according to our legislation: biocentres, biocorridors, interaction elements, according to foreign literature: core areas (Jongman, 1996; Nowicki et al., 1996).

The proposals of TSES should also focus on strengthening the overall spatial stability of individual REPGES and geoecological regions. When selecting elements of TSES, preference should be given to sites with a natural species composition, in the absence of these, it should be proposed to create new sites with natural vegetation so that all types of REPGES are represented and that a representative type of geoecosystem is preserved in each region.

In the Trnava district, there is no element of supra-regional or regional character in up to 21 types of REPGES. Supra-regional elements of TSES are represented in 67 (69.7\%) types of REPGES, regional in $64(66.7 \%)$ types of REPGES (overlap of regional and supra-regional elements of TSES was found in 57 types of REPGES).

From the point of view of preservation and protection of REPGES it is necessary to ensure protection of those REPGES, where elements of TSES of different hierarchical order are located. For those REPGES (21 types) where the TSES elements are not currently identified, it is necessary to create them and subsequently to provide them with the necessary protection. It is also necessary to establish a set of ecostabilizing measures that will not only protect individual types of ecosystems, but also ensure the efficient use of their ecosystem services.

\section{Acknowledgements}

„This publication was produced through support under the Operational Program Research and Innovation for the project: Assessment of landscape changes and their impact on the environment, NFP313010X649, co-financed by the European Fund regional development."We are grateful to Mgr. Silvia Chasníková for English proofreading.

\section{References}

Buček, A. \& Lacina J. (2000). Geobiocenologie II. Brno: MZLU.

Bunce, R.G.H., Barr, C.J., Clarke, R.T., Howard, D.C. \& Lane A.M.J. (1996). Land classification for strategic ecological survey. J. Environ. Manag., 47, 37-60. DOI: 10.1006/jema.1996.0034.

Burkhard, B., Kandziora, M., Hou, Y. \& Müller F. (2014). Ecosystem service potentials, flows and demand - concepts for spatial localisation, indication and quantification. Landscape Online, 34, 1-32. DOI: 10.3097/LO.201434.

Costanza, R. (2016). Ecosystem services and theory and practice. In M. Potschin, R. Haines-Young, R. Fish \& R. Kerry Turner (Eds.), Routledge handbook of ecosystem services (pp. 15-24). London, New York: Routledge.

De Groot, R.S., Alkemade, R., Braat, L., Hein, L. \& Willemen L. (2010). Challenges in integrating the concept of ecosystem services and values in landscape planning, management and decision making. Ecological Complexity, 7, 260-272. DOI: 10.1016/j.ecocom.2009.10.006.

European Commission (2011). Communication from the Commission to the European Parliament, The Council, The Economic and Social Committee and the Committee of the Regions. Our life insurance, our natural capital: an EU biodiversity strategy to 2020. http://ec.europa.eu/environment/nature/biodiversity/comm2006/pdf/2020/1_ EN_ACT_part1_v7[1].pdf 
Fábos, J.Gy. \& Ryan R.L. (2004). International greenway planning: an introduction. Landsc. Urban Plann., 68(2-3), 143-146. DOI: 10.1016/S0169-2046(03)00155-5.

Forman, R.T.T. (1990). Ecologically sustainable landscapes: The role of spatial configuration. In I.S. Zonneveld \& R.T.T. Forman (Eds.), Changing landscapes: An ecological perspectives (pp. 261-278). New York: Springer Verlag.

Haines-Young, R. \& Potschin M. (2012). Common International Classification of Ecosystem Services (CICES): 1035 Consultation on Version 4, August-December 2012. EEA Framework Contract No EEA/IEA/09/003.

Izakovičová, Z., Hrnčiarová, T., Miklós, L., Tremboš, P., Ružičková, J., Liška, M., Králik, J., Moyzeová, M., Š́́bl, J. \& Pauditšová E. (2000): Metodické pokyny na vypracovanie projektov regionálních ÚSES a miestnych ÚSES. Bratislava: Združenie Krajina 21.

Izakovičová, Z., Miklós, L., Moyzeová, M., Špilárová, I., Kočický, D., Halada, L., Gajdoš, P., Špulerová, J., Baránková, Z., Štefunková, D., Kenderessy, P., Šatalová, B., Dobrovodská, M., Hrnčiarová, T., David, S. \& Krnáčová Z. (2011). Model reprezentatívnych geoekosystémov na regionálnej úrovni. Bratislava: ÚKE SAV.

Izakovičová, Z., Bezák, P., Mederly, P. \& Špulerová J. (2017). Uplatňovanie konceptu ekosystémových služieb v plánovacej a riadiacej praxi v Slovenskej republike - výsledky projektu OpenNESS na prípadovej štúdii Trnava. Životné Prostredie, 51(4), 198-204.

Izakovičová, Z. \& Świąder M. (2017). Building ecological networks in Slovakia and Poland. Ekológia (Bratislava), 36(4), 303-322. DOI: 10.1515/eko-2017-0025.

Jongman, R.H.G. (1996). Research priorities: scientific concepts and criteria. In Perspectives on ecological networks. European Centre for Nature Conservation. Man and Nature, 1(14), 151-160.

Jongman, R.H.G. \& Kristiansen I. (2001). National and regional approaches for ecological networks in Europe. Nature and Environment, 110. Strasbourg: Council of Europe Publishing.

Jongman, R.H.G., Bunce, R.G.H., Metzger, M.J., Mücher, C.A., Howard, D.C. \& Mateus V.L. (2006). Objectives and applications of a statistical environmental stratification of Europe. Landsc. Ecol., 21, 409-419. DOI: 10.1007/ s10980-005-6428-0.

Michalko, J., Berta, J. \& Magic D. (1986). Geobotanická mapa ČSSR. Bratislava: Veda, vydavatel'stvo SAV.

Miklós, L., Izakovičová, Z., Boltižiar, M., Diviaková, A., Grotkovská, L., Hrnčiarová, T., Imrichová, Z., Kočická, E., Kočický, D., Kenderessy, P., Mojses, M., Moyzeová, M., Petrovič, F., Špinerová, A., Špulerová, J., Štefunková, D., Valkovcová, Z. \& Zvara I. (2006). Atlas reprezentatívnych geoekosystémov Slovenska. Bratislava: ÚKE SAV, MŽP SR, Banská Štiavnica: Esprit, s.r.o.

Miklós, L., Diviaková, A. \& Izakovičová Z. (2018). Ecological networks and territorial systems of ecological stability. Cham: Springer.

Nowicki, P., Bennet, G., Middleton, D., Rientjes, S. \& Wolters R. (Eds.) (1996). Perspectives on ecological networks. European Centre for Nature Conservation. Man and Nature, 1(14), 161-192.

Odum, E.P. (1975): Ecology: The link between the natural and the social sciences. London-New York-Sidney-Toronto: Holt Rinehart and Winston.

Reháčková, T. \& Pauditšová E. (2003). Ecological networks in urban areas - new approaches. Ekológia (Bratislava), 22(2), 108-118. 